\title{
FAKTOR-FAKTOR YANG MEMPENGARUHI MINAT BERWIRAUSAHA MAHASISWA PRODI EKONOMI SYARIAH UNIVERSITAS ISLAM RIAU
}

\author{
Zulkifli $^{1}$ \& Nur Meifiani ${ }^{2}$ \\ ${ }^{1 \& 2}$ Fakultas Agama Islam, Universitas Islam Riau \\ E-mail : zulkiflirusby@yahoo.com,nurmeifiani10@gmail.com
}

\begin{abstract}
ABSTRAK
Penelitian ini bertujuan untuk mengetahui pengaruh faktor pribadi, kemasyarakatan, lingkungan, dan motivasi terhadap minat berwirausaha mahasiswa Prodi Ekonomi Syariah Universitas Islam Riau. Jenis penelitian ini adalah penelitian lapangan (field research). Metode penelitian adalah kuantitatif. Sampel penelitian adalah mahasiswa Prodi Ekonomi Syariah Universitas Islam Riau sebanyak 76 orang. Teknik pengambilan sampel menggunakan stratified random sampling. Teknik pengumpulan data menggunakan kuesioner dan dokumentasi. Analisis data menggunakan analisis regresi linear berganda dengan SPSS for Windows Versi 24,0. Hasil penelitian menunjukkan bahwa uji parsial terdapat pengaruh yang signifikan antara faktor pribadi, kemasyarakatan, lingkungan dan motivasi terhadap minat berwirausaha mahasiswa Prodi Ekonomi Syariah Universitas Islam Riau. Nilai koefisien korelasi sebesar 79,4\%, sehingga memiliki hubungan yang kuat. Kelima variabel bebas secara bersama-sama mempunyai pengaruh yang signifikan terhadap minat berwirausaha dapat dilihat dari $\mathrm{F}_{\text {hitung }}$ lebih besar dari $\mathrm{F}_{\text {tabel }}(30,214>2,74)$. Kesimpulan terdapat kontribusi antara kelima variabel X terhadap variabel Y. Nilai koefisien determinasi sebesar 60,9\% dan sisanya sebesar 39,1\% dipengaruhi oleh variabel lain yang tidak dimasukkan dalam penelitian ini. Jadi, kelima variabel bebas (X) mempengaruhi minat berwirausaha sehingga memiliki hubungan yang kuat.
\end{abstract}

Kata Kunci : Minat, Wirausaha, Ekonomi Syariah.

\begin{abstract}
This study aims to determine the influence of personal, sociological, environmental, and motivational factors on the entrepreneurial interests of students of Sharia Economics Study Program of Riau Islamic University. This type of research is field research. The research method is quantitative. The research sample was 76 students of Sharia Economics Study Program of Riau Islamic University. Sampling techniques using Stratified Random Sampling. Data collection techniques using questionnaires and documentation. Data analysis uses multiple linear regression analysis with SPSS for Windows Version 24.0. The results showed that the partial test had a significant influence between personal, societal, environmental and motivational factors on the entrepreneurial interests of students of The Islamic Economics Study Program of Riau Islamic University. The correlation coefficient value is $79.4 \%$, so it has a strong relationship. The five of independent variables together have a significant influence on entrepreneurial interests can be seen from $F_{-}$count greater than $F_{-}$table $(30,214$ > 2.74). The conclusion is that the contribution between the five variables $X$ to the variable $Y$. The value of the coefficient of determination is $60.9 \%$ and the remaining $39.1 \%$ is influenced by other variables not included in this study. Thus, the five of independent variables $(X)$ affect entrepreneurial interests so that they have a strong relationship.
\end{abstract}

Keywords: Interests, Entrepreneurship, Sharia Economics. 


\section{PENDAHULUAN}

Zaman yang berkembang saat ini menuntut kita untuk lebih kritis ketika beradaptasi dengan lingkungan masyarakat. Jumlah pengangguran yang banyak dapat menjadi kendala dalam memajukan perekonomian. Disini dapat dilihat bahwa betapa pentingnya dunia usaha dalam perekonomian. Pertumbuhan usaha di Indonesia tahun 2016 masih tergolong sangat kecil, total persentase pengusaha yang dimiliki Indonesia sebanyak 1,5\% dari total jumlah penduduk sebanyak 252 juta orang. Indonesia masih perlu menambah jumlah pengusaha sekitar 1,7 juta untuk mencapai target $2 \%$. Perbandingan ini cukup jauh jika kita bandingkan dengan negara lain seperti : Negara Singapura yang diketahui total pengusahanya sebanyak 7\%, Negara Malaysia 5\%, Negara Thailand 4,5\%, dan Negara Vietnam sebesar 3,3\% (Mahanani dan Sari, 2018).

Fenomena yang terjadi disebabkan karena masih rendahnya motivasi dan minat masyarakat Indonesia. Pola pikir masyarakat Indonesia perlu diubah, Jika tidak Indonesia akan mempunyai banyak permasalahan, salah satunya semakin bertambahnya tingkat pengangguran, karena tidak seimbang antara banyaknya kesempatan kerja dengan orang yang mencari kerja membuat tingkat pengangguran di Indonesia cukup tinggi termasuk pengangguran terdidik (Primandaru, 2017).

Berwirausaha dianggap menjadi solusi untuk permasalahan di atas karena semakin banyaknya jumlah pengusaha di Indonesia maka akan banyak pula jumlah lapangan kerja yang tersedia sehingga membuat tingkat pengangguran di Indonesia ini berkurang. Ini akan berdampak baik untuk perekonomian di Indonesia.

Perguruan Tinggi mempunyai peranan besar dalam melahirkan sarjana muda yang berkualitas. Mahasiswa akan dibekali berbagai macam ilmu pengetahuan mengenai kewirausahaan dengan memberikan mata kuliah kewirausahaan dengan harapan dengan adanya ilmu tersebut maka timbulah minat mahasiswa untuk berwirausaha.

Minat berwirausaha yaitu keinginan dan ketertarikan seseorang dalam dunia usaha. Mereka berusaha menggunakan peluang yang ada untuk dijadikan usaha dengan bekal tekat, kemauan yang kuat dan berani untuk mengambil resiko dan menghadapi segala tantangan. Seorang wirausahawan harus kreatif dan inovatif. Semua itu diperlukan untuk perkembangan dan keberhasilan sebuah usaha.

Universitas Islam Riau adalah perguruan tinggi Islam swasta yang ada di Kota Pekanbaru telah berupaya menanamkan dan membekali para mahasiswa untuk menjadi wirausahawan. Adapun upaya yang dilakukan oleh pihak Universitas ialah dengan memberikan mata kuliah kewirausahaan pada program studi yang ada di Universitas Islam Riau, salah satunya adalah Program Studi Ekonomi Syariah yang ada di Fakultas Agama Islam.

Para sarjana lulusan Program Studi Ekonomi Syariah ini telah dibekali ilmu teoritis dan praktis yang diharapkan para sarjana tidak menjadi pelamar pekerjaan, tetapi mereka mampu menjadi pengusaha atau pembuat lapangan kerja. Meskipun terlebih dahulu harus memulai dari usaha yang kecil. (Astuti dan Maharani, 2015)

\section{TINJAUAN PUSTAKA}

\section{Teori Minat}

Minat (interest) merupakan ketertarikan yang besar terhadap sesuatu. Ketertarikan dapat dilihat dari sebuah partisipasi yang menunjukkan seseorang ingin melakukan sesuatu yang ia senangi dan akan melakukan upaya untuk mempelajarinya (Syah, 2011).

Minat adalah senang yang ada dalam diri seseorang, tanpa ada keterpaksaan dari pihak lain. Minat dapat dihubungkan dengan penerimaan dalam diri seseorang dengan hal yang berada diluar diri. Crow and crow menyatakan minat sangat berhubungan dengan tindakan seseorang ketika ia 
berhadapan dengan orang, atau berhubungan dengan kegiatan, maupun berbagai pengalaman yang dipicu oleh kegiatan tersebut (Djali, 2013).

Menurut Hurlock dalam Kambuaya (2015) minat terbagi menjadi 2 aspek, adalah sebagai berikut :

a. Aspek kognitif : Dilihat berdasarkan pengalaman pribadi dan lingkungan sekitar.

b. Aspek afektif : menunjukkan bagaimana minat dapat berkembang melalui dukungan di lingkungan sekitar.

\section{Faktor-Faktor yang Mempengaruhi Minat}

Menurut Crow dan Crow dalam Fauzan (2012) Ada empat faktor yang dapat mempengaruhi minat yaitu :

1. Ekonomis

Status ini berhubungan dengan kedudukan keluarga dalam masyarakat. Ini dapat dilihat pendapatan perbulan, dan pendapatan berdasarkan harga barang pokok yang ada di pasaran.

2. Pendidikan

Adalah salah satu faktor yang bisa mempengaruhi minat. Orang yang berpendidikan mampu memberi pengaruh yang besar pada orang lain agar mereka melakukan sesuatu yang ia harapkan.

3. Situasional (orang dan lingkungan)

Lingkungan adalah keadaan yang berhubungan dengan orang lain terutama orang-orang disekitar kita. Hubungan tersebut dapat terjadi karena seseorang memiliki daya tarik atau keunggulan tertentu. Sehingga orang lain akan simpati kepadanya.

4. Keadaan Psikis

Keadaan Psikis akan berpengaruh kepada tingkah laku dan pola pikir seseorang. Keadaan psikis ini memberikan pengaruh yang sangat besar terhadap minat. Keadaan psikis tersebut terdiri dari pemikiran, motivasi, pembelajaran, sikap, dan keyakinan yang teguh.

\section{Kewirausahaan}

Kewirausahaan adalah proses kreatifitas dan inovasi yang dilakukan untuk menghasilkan keuntungan dari suatu produk/barang yang bisa berguna bagi pengusaha dan juga masyarakat (Adhitama, 2014).

Kewirausahaan adalah kemampuan untuk mendapatkan peluang usaha dengan cara mengembangkan kreativitas dan inovatif yang ada dalam dirinya. Kreativitas untuk menciptakan sesuatu yang baru terutama yang memiliki keunikan tersendiri dapat dijadikan nilai tambah untuk mendapatkan peluang tersebut (Ayuningtias dan Ekawati, 2015).

Menurut Daryanto dan Cahyono (2013) ada beberapa manfaat kewirausahaan yaitu:

1. Menambah lapangan kerja,

2. Memberikan panutan untuk bekerja secara gigih dan tekun,

3. Mendidik para pekerja untuk disiplin,

4. Mandiri,

5. Tekun dan jujur dalam bekerja, dan membuka kesempatan kerja yang luas.

\section{Faktor-Faktor yang Mempengaruhi Minat Berwirausaha}

Ada 3 faktor kritis yang mempengaruhi minat dalam berwirausaha, yaitu : (Alma, 2017)

1. Personal (Pribadi)

Alma menyatakan bahwa faktor personal (pribadi) berkaitan dengan kepribadian seseorang. Seseorang akan termotivasi untuk membuka usaha karena ingin mendapatkan kebebasan dalam berbisnis dan tidak terikat oleh pihak manapun. Selain itu orang yang 
membuka usaha akan ingin mendapatkan uang, sedangkan orang yang ingin membuka usaha untuk kesenangan, hobi, menyukai tantangan ataupun kesenangan.

2. Sociological (Kemasyarakatan)

Sociological (kemasyarakatan) berkaitan dengan hubungan keluarga dan sosial. Ada berbagai hal yang berkaitan dengan hubungan keluarga, misalnya hubungan seseorang terhadap orang tua, dan juga keluarga. Sedangkan hubungan sosial bisa berkaitan dengan pekerjaan, teman, dan status sosial (Alma, 2017)

Tanggung jawab sosial terhadap orang tua merupakan faktor sosial yang dapat mempengaruhi minat. Seorang anak akan lebih cenderung menjadi seorang wirausahawan apabila dia terlahir dari orang yang seorang wirausahawan. Hal ini merupakan inspirasi bagi setiap anak untuk berwirausaha. (Alma 2017)

3. Environmental (Lingkungan)

Environmental(Lingkungan) berkaitan dengan hubungan terhadap lingkungan. Adapun beberapa faktor lingkungan diantaranya adalah peluang, para pesaing, sumber daya yang ada disekitar, dan kebijakan yang diberikan oleh pemerintah.

Ada beberapa indikator minat berwirausaha adalah : Alma (2017)

a) Percaya diri

Adalah kepercayaan diri seseorang terhadap kemampuan dirinya. Seseorang dikatakan matang jasmani dan rohani apabila memiliki kepercayaan diri yang tinggi ini terlihat dari sikap dia yang tidak bergantung dengan pihak lain.

b) Berorientasi pada tugas dan hasil

Adalah seseorang tidak mendahulukan kemampuan, baru prestasi kemudian. Tetapi, lebih memprioritaskan prestasi yang dia miliki. c) Pengambilan Resiko

Seorang wirausaha harus siap menghadapi segala resiko dan tantangan. Buatlah perhitungan yang matang, sehingga resiko yang akan diperoleh pun semakin sedikit.

d) Kepemimpinan

Seorang pemimpin dalam Islam harus memiliki keberanian untuk menegakkan kebenaran. Pemimpin harus melakukan kewajibannya dengan penuh tanggung jawab.

e) Keorisinilan

Individu yang memiliki orisinil dia akan memiliki ide sendiri, dan memiliki kemampuan untuk menciptakan sesuatu yang baru. Salah satunya dengan cara mengkombinasikan komponen pada produk sudah ada agar dapat menciptakan produk baru.

f) Berorientasi ke masa depan

Pengusaha harus mempunyai visi untuk masa yang akan datang, dia harus tahu apa yang mesti dilakukan dan bagaimana cara untuk mewujudkannya. Maka dari itu, seorang wirausaha harus membuat rencana baik, sehingga apa yang ingin dilaksanakan sudah jelas.

g) Kreativitas

Kreativitas sangat diperlukan dalam menghadapi persaingan dalam dunia usaha. Dunia bisnis sangat memerlukan sumberdaya manusia yang kreatif, inovatif dan memiliki jiwa usaha.

\section{Kewirausahaan dalam Perspektif Islam}

Allah SWT menganjurkan umat Islam untuk mencukupi kebutuhannya dan tidak bergantung pada pihak lain. Ini berarti bahwa Islam tidak hanya memenuhi kebahagiaan rohani, kebahagiaan jiwa dan kebahagiaan spiritual, semuanya menuju satu kebahagiaan hidup di alam akhirat. Islam juga 
memperhatikan pentingnya mencapai kebahagiaan hidup di dunia ini. Dengan tegas Islam tidak pernah melarang umat menjadi kaya. Malah sebaliknya Islam memperingatkan agar tidak jatuh ke dalam kemiskinan (Farid, 2017).

Kewirausahaan menggambarkan segala aktivitas yang dilakukan baik individu atau kelompok untuk membuat produk yang diperlukan untuk kehidupan sehari-hari. Kewirausahaan merupakan kegiatan yang dilakukan manusia guna mendapatkan penghasilan atau rezeki yang digunakan untuk memenuhi kebutuhan dan keinginan hidupnya. Ini bisa dilakukan dengan cara mengelola secara efektif dan efisien sumberdaya ekonomi yang ada. (Norvadewi, 2015).

\section{Prinsip-Prinsip Wirausaha dalam Islam}

Ada beberapa prinsip wirausaha Rasulullah adalah (Farid, 2017) :

1. Kerelaan dalam Usaha Perdagangan

Dalam Islam perdagangan harus dilakukan dengan kerelaan antara kedua belah pihak, tidak boleh ada keterpakasaan dari setiap pihak.

2. Keadilan

Dalam Islam keadilan sangat penting ketika seseorang melakukan kegiatan perdagangan. Allah SWT memerintahkan kita selaku umat muslim untuk menimbang dan mengukur timbangan atau takaran dengan benar.

\section{Akhlak yang Mulia}

Seorang pedagang harus memiliki sifat dan akhlak yang baik. Akhlak menggambarkan sikap seseorang yang ditunjukkan melalui perbuatan sehingga dapat mencerminkan sikap yang baik atau buruk. Baik buruk pekerjaan seseorang ditentukan akhlak yang dimilikinya.

4. Transaksi Perdagangan
Ada 3 hal dalam Islam yang dibutuhkan untuk melakukan suatu traksaksi, yaitu : (Farid, 2017)

a. Akad atau transaksi

Akad transaksi merupakan isi dan tujuan dari perjanjian. Bentuk kata-kata dalam jual beli, yaitu penjual mengucapkan bahwa ia menjual (ijab) dan pembeli harus mengucapkan bahwa ia membeli atau menerima (Qabul).

b. Objek transaksi

Objek transaksi adalah barang yang akan diperjualbelikan. Barang yang menjadi objek transaksi adalah tertentu, baik jenis, sifat, dan jumlahnya.

c. Subjek transaksi

Subjek transaksi adalah orang yang melakukan transaksi jual beli. Syarat bagi orang yang menjadi subjek transaksi menurut Islam yaitu : dewasa (baligh), sehat akal dan mental (tidak gila), atas kehendak sendiri, bukan karena paksaan orang lain, boleh menggunakan hartanya.

Adapun motivation (motivasi) yang mendorong seseorang untuk berwirausaha dalam perdagangan menurut ajaran Islam, yaitu :

\section{Berdagang Buat Mencari Untung}

Salah satu tujuan menjalankan kegiatan perdagangan adalah ingin memperoleh keuntungan (laba). Tetapi terkadang ada sebagian orang yang berupaya mencari keuntungan dengan cara yang tidak baik. Hal seperti ini sangat dilarang oleh Agama Islam. Rasulullah SAW bersabda

Artinya : "sesungguhnya Allah menyukai kemudahan dalam menjual dan membeli, dan dalam menagih haknya (dari orang lain)." (H.R. Tirmidzi). 
2. Berdagang Adalah Hobi

Konsep berdagang adalah hobi banyak dianut oleh para pedagang dari Cina. Mereka menekuni kegiatan berdagang ini dengan sebaik-baiknya dengan berbagai upaya salah satunya dengan open display, windor display, interior display close display.

3. Berdagang Adalah Ibadah

Dalam Islam, berdagang merupakan salah ibadah kepada Allah SWT. Apa yang kita lakukan di dunia ini harus kita niatkan semata-mata untuk beribadah kepada Allah SWT sehingga Allah SWT memberikan keberkahannya. Berwirausaha adalah upaya yang dilakukan untuk mendapatkan rezeki. Dengan berwirausaha kita bisa membantu orang lain dengan memberikan peluang kerja dan kita juga bisa melakukan kebaikan lainnya.

4. Perintah Kerja Keras

Motivasi seseorang untuk bekerja dengan sungguh-sungguh bisa timbul dari kemauannya untuk bekerja keras. Allah SWT memerintahkan kita untuk bertawakal dan bekerja keras, semua itu harus dilakukan agar kita berhasil dan mampu mengubah nasib menjadi lebih baik dan senantiasa berdoa meminta pertolongan kepada Allah SWT, karena hanya Allah SWT yang bisa menentukan bagaimana akhir dari segala usaha yang dilakukan.

5. Perdagangan/Berwirasuaha Pekerjaan Mulia Dalam Islam

Berdagaang/berwirausaha merupakan pekerjaan yang mulia dalam Islam. Rasulullah SAW bersabda:

Artinya : "Wahai Rasulullah, mata pencaharian apakah yang paling baik?" Beliau Bersabda, "Pekerjaan seorang laki-laki dengan tangannya sendiri dan setiap jual beli yang mabrur (diberkahi)." (H.R. Ahmad)

\section{METODE PENELITIAN}

\section{Desain Penelitian}

Penelitian ini merupakan penelitian lapangan (Field Research) dengan metode kuantitatif. Desain penelitian ini adalah kausalitas yaitu penelitian yang disusun untuk meneliti bahwa adanya kemungkinan hubungan sebab akibat antar variabel (Sanusi, 2016).

Penelitian ini dilakukan di Fakultas Agama Islam Universitas Islam Riau. Subjek penelitian ini adalah Mahasiswa Prodi Ekonomi Syariah Universitas Islam Riau. Sedangkan objek penelitian adalah FaktorFaktor yang Mempengaruhi Minat Berwirausaha Mahasiswa Prodi Ekonomi Syariah Universitas Islam Riau.

\section{Populasi}

Populasi dalam penelitian ini adalah Mahasiswa Program Studi Ekonomi Syariah Fakultas Agama Islam Riau mulai dari Tahun Angkatan 2013 sampai 2019 sebanyak 319 mahasiswa.

\section{Sampel}

Adapun jumlah sampel ditentukan berdasarkan rumus Slovin (Sanusi, 2016, 101). Jadi dalam Penelitian ini ukuran sampelnya adalah sebanyak 76 orang, dengan teknik pengambilan sampel mengunakan Stratified Random Sampling yaitu teknik yang digunakan apabila populasinya tidak homogen (Sanusi, 2016).

\section{Teknik Pengumpulan Data}

Teknik pengumpulan data yang digunakan adalah:

1. Kuesioner (angket) adalah teknik pengumpulan data dengan memberikan daftar penyataan kepada responden yang bersedia memberikan respon (Riduwan, 2018).

2. Dokumentasi adalah dengan memperoleh data langsung yang diperoleh dari tempat penelitian, meliputi buku yang relevan, 
peraturan, laporan kegiatan, foto, film, dokumenter, data penelitian yang relevan (Riduwan, 2018).

\section{Teknik Pengolahan Data}

Pada penelitian kuantitatif, pengolahan data dilakukan dengan melalui tahap penyuntingan (editing), Pengkodean (coding), dan Pentabulasian (tabulating). (Misbahudin dan Hasan, 2013). Teknik analisis data penelitian ini menggunakan metode kuantitatif. Metode kuantitatif digunakan untuk menganalisis secara statistik dengan menggunakan SPSS for windows versi 24.0.

\section{HASIL DAN PEMBAHASAN}

\section{Uji Validitas}

Uji validitas digunakan untuk mengetahui apakah pernyataan tersebut dinyatakan layak atau tidak untuk dianalisis. Suatu pernyataan akan di katakan valid apabila $r_{\text {hitung }}>r_{\text {tabel. }}$.

Tabel 1. Hasil Uji Validitas

\begin{tabular}{ccccc}
\hline Variabel & Item Pernyataan & $\begin{array}{c}\text { Corrected Item-Total } \\
\text { Correlation }(\boldsymbol{r} \text { Hitung) }\end{array}$ & $\begin{array}{c}\mathbf{R} \text { tabel } \\
\boldsymbol{\alpha}=\mathbf{0 , 0 5}\end{array}$ & $\begin{array}{c}\text { Keterangan } \\
\text { Hasil }\end{array}$ \\
\hline $\mathbf{X 1}$ & 0,400 & 0,227 & Valid \\
\hline & Item 1 & 0,484 & 0,227 & Valid \\
\hline & Item 2 & 0,270 & 0,227 & Valid \\
\hline Item 3 & 0,436 & 0,227 & Valid \\
\hline Item 4 & 0,464 & 0,227 & Valid \\
\hline & Item 5 & 0,451 & 0,227 & Valid \\
\hline & Item 6 & 0,603 & 0,227 & Valid \\
\hline Item 7 & 0,422 & 0,227 & Valid \\
\hline Item 8 & Item 9 & 0,466 & Valid \\
\hline & Item 10 & 0,586 & 0,227 & Valid \\
\hline Item 11 & 0,503 & 0,227 & Valid \\
\hline Item 12 & 0,647 & 0,227 & Valid \\
\hline & Item 13 & 0,436 & 0,227 & Valid \\
\hline Item 14 & 0,471 & 0,227 & Valid \\
\hline Item 15 & 0,576 & 0,227 & Valid \\
\hline Item 16 & 0,552 & 0,227 & Valid \\
\hline Item 17 & 0,636 & 0,227 & Valid \\
\hline Item 18 & 0,621 & 0,227 & Valid \\
\hline Item 19 & 0,478 & 0,227 & Valid \\
\hline Item 20 & 0,227 & Valid \\
\hline Item 21 & 0,575 & 0,227 & Valid \\
\hline Item 22 & 0,565 & 0,227 & Valid \\
\hline Item 23 & 0,336 & 0,227 & Valid \\
\hline Item 24 & 0,623 & 0,227 & Valid \\
\hline
\end{tabular}

Sumber : Data Olahan (2020)

Diketahui nilai $r$ tabel sebesar 0,227 (lihat tabel r) dan nilai ini dibandingkan dengan nilai $r_{\text {hitung. Nilai }} r_{\text {hitung dalam uji ini }}$ pada kolom Item-Total Statistics (Corrected Item-Total Correlation). Dari 25 pernyataan di bawah ini menunjukkan bahwa semua $r_{\text {hitung }}>r_{\text {tabel }}$. Sehingga seluruh item variabel dinyatakan valid dan layak untuk dianalisis.

\section{Uji Reliabilitas}

Uji reliabilitas digunakan dengan teknik Cronbach's Alpha dimana instrumen dapat dikatakan handal atau reliabel apabila memiliki koefisien kehandalan $>0,6$. Jumlah butir pernyataan yang dapat diuji pada uji reliabilitas sebanyak 25 butir pernyataan. 
Tabel 2. Hasil Uji Reliabilitas

\begin{tabular}{|c|c|c|c|c|}
\hline Variabel & Item Pernyataan & $\begin{array}{l}\text { Corrected Item-Total } \\
\text { Correlation (r Hitung) }\end{array}$ & $\begin{array}{l}\text { Cronbach's } \\
\text { Alpha }\end{array}$ & Keterangan Hasil \\
\hline \multirow[t]{5}{*}{$\mathbf{X 1}$} & Item 1 & 0,903 & 0,6 & Reliabel \\
\hline & Item 2 & 0,901 & 0,6 & Reliabel \\
\hline & Item 3 & 0,904 & 0,6 & Reliabel \\
\hline & Item 4 & 0,902 & 0,6 & Reliabel \\
\hline & Item 5 & 0,901 & 0,6 & Reliabel \\
\hline \multirow[t]{4}{*}{$\mathbf{X} 2$} & Item 6 & 0,902 & 0,6 & Reliabel \\
\hline & Item 7 & 0,898 & 0,6 & Reliabel \\
\hline & Item 8 & 0,902 & 0,6 & Reliabel \\
\hline & Item 9 & 0,902 & 0,6 & Reliabel \\
\hline \multirow[t]{4}{*}{$\mathbf{X 3}$} & Item 10 & 0,899 & 0,6 & Reliabel \\
\hline & Item 11 & 0,901 & 0,6 & Reliabel \\
\hline & Item 12 & 0,897 & 0,6 & Reliabel \\
\hline & Item 13 & 0,902 & 0,6 & Reliabel \\
\hline \multirow[t]{5}{*}{$\mathrm{X} 4$} & Item 14 & 0,901 & 0,6 & Reliabel \\
\hline & Item 15 & 0,899 & 0,6 & Reliabel \\
\hline & Item 16 & 0,900 & 0,6 & Reliabel \\
\hline & Item 17 & 0,898 & 0,6 & Reliabel \\
\hline & Item 18 & 0,898 & 0,6 & Reliabel \\
\hline \multirow[t]{7}{*}{$\mathbf{Y}$} & Item 19 & 0,901 & 0,6 & Reliabel \\
\hline & Item 20 & 0,900 & 0,6 & Reliabel \\
\hline & Item 21 & 0,900 & 0,6 & Reliabel \\
\hline & Item 22 & 0,904 & 0,6 & Reliabel \\
\hline & Item 23 & 0,898 & 0,6 & Reliabel \\
\hline & Item 24 & 0,900 & 0,6 & Reliabel \\
\hline & Item 25 & 0,902 & 0,6 & Reliabel \\
\hline
\end{tabular}

Sumber : Data Olahan (2020)

Berdasarkan uji reliabilitas dengan menggunakan korelasi Product Moment dan uji reliabilitas menggunakan Cronbach's Alpha di atas dapat disimpulkan bahwa 25 butir pernyataan pada tabel di bawah dinyatakan reliabel karena koefisien kehandalan $>0,6$.

\section{Uji Asumsi Klasik}

\section{Uji Normalitas}

Uji normalitas bertujuan untuk menguji apakah dalam model regresi, variabel pengganggu atau residual memiliki distribusi normal atau tidak. Untuk mendeteksi apakah residual berdistribusi normal atau tidak maka menggunakan uji Kolmogorov-Smirnov. Jika sig > 0,05 maka data pada variabel berdistribusi normal.

Tabel 3. Uji Normalitas

\begin{tabular}{llr}
\hline \multicolumn{2}{c}{ One-Sample Kolmogorov-Smirnov Test } \\
\hline & & Studentized Deleted Residual \\
\hline $\mathrm{N}$ & \multicolumn{1}{c}{ Mean } & 76 \\
\cline { 2 - 3 } Normal Parameters ${ }^{\mathrm{a}, \mathrm{b}}$ & Std. Deviation &, 0012905 \\
\hline Most Extreme Differences & Absolute & 1,02629654 \\
\cline { 2 - 3 } & Positive &, 072 \\
\cline { 2 - 3 } & Negative &, 072 \\
\hline Test Statistic & &,- 065 \\
\hline Asymp. Sig. (2-tailed) & &, 072 \\
\hline
\end{tabular}

Sumber : Data Olahan (2020) 
Dari output di atas dapat diketahui bahwa nilai signifikasi (Sig) pada Kolmogorov-Smirnov sebesar 0,200. Karena signifikasi lebih dari 0,05 maka residual terdistibusi dengan normal.

\section{Uji Multikolinearitas}

Pendeteksian pada Multikolinearitas dapat dilakukan dengan melihat nilai VIF dan nilai Tolerence dari hasil analisis regresi. Variabel akan dinyatakan tidak terjadi masalah multikolinearitas apabila nilai VIF < 10 dan nilai Tolerence $>0,1$.

Tabel 4. Uji Multikolinearitas

\begin{tabular}{|c|c|c|c|}
\hline \multicolumn{4}{|c|}{ Coefficients $^{a}$} \\
\hline & & \multicolumn{2}{|c|}{ Collinearity Statistics } \\
\hline \multicolumn{2}{|c|}{ Model } & Tolerance & VIF \\
\hline \multirow[t]{5}{*}{1} & (Constant) & & \\
\hline & PRIBADI & ,597 & 1,675 \\
\hline & KEMASYARAKATAN & ,549 & 1,820 \\
\hline & LINGKUNGAN & ,444 & 2,250 \\
\hline & $\overline{\text { MOTIVASI }}$ & ,469 & 2,133 \\
\hline
\end{tabular}

Sumber : Data Olahan (2020)

Diketahui untuk ke empat variabel nilai VIF $<10$ dan nilai Tolerence $>0,1$, maka disimpulkan bahwa model regresi maka tidak terjadi masalah multikolinearitas.

\section{Uji Heteroskedastisitas}

Gejala heteroskedastisitas diuji dengan metode Glejser dengan cara menyusun regresi antara nilai absolut residual dengan variabel bebas. Apabila variabel bebas tidak berpengaruh signifikan terhadap absolut residual $(\alpha=0,05)$, maka model regresi tidak terjadi gejala heteroskedastisitas (Sanusi, 2016).

\section{Gambar 1. Uji Heteroskedastisitas}

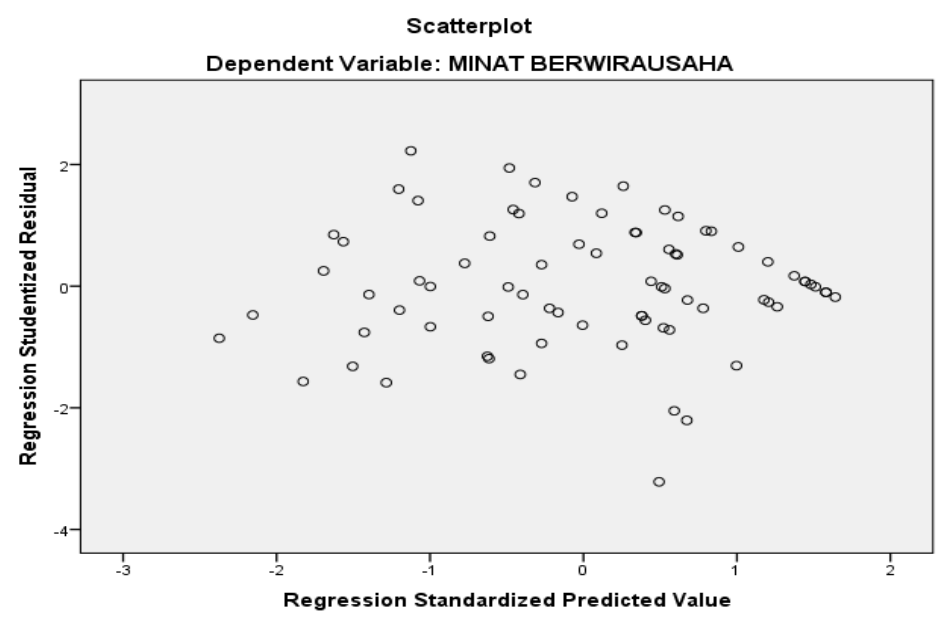

Sumber : Data Olahan (2020)

Dari output di atas hasil uji di bawah angka 0 pada sumbu Y, jadi dapat heteroskedastisitas ialah titik menyebar disimpulkan bahwa tidak terjadi masalah dengan pola yang tidak jelas yaitu di atas dan heteroskedastisitas pada model regresi. 


\section{Analisis Regresi Linear Berganda}

Hasil perhitungan pada analisis regresi linear berganda melalui SPSS For Windows
Versi 24.0, maka diperolah nilai untuk variabel bebas dan variabel terikat yang dijelaskan pada tabel di samping ini :

Tabel 5. Analisis Regresi Linear Berganda

\begin{tabular}{lrrrr}
\hline \multicolumn{5}{c}{ Coefficients $^{\mathbf{a}}$} \\
\hline \multirow{2}{*}{ Model } & \multicolumn{3}{c}{ Unstandardized Coefficients } & \multicolumn{2}{c}{ Standardized Coefficients } \\
\cline { 2 - 5 } & \multicolumn{1}{c}{ B } & Std. Error & Beta \\
\hline 1 (Constant) & 5,140 & 2,540 &, 362 \\
\cline { 2 - 5 } &, 533 &, 138 &, 255 \\
\hline PRIBADI &, 397 &, 124 &, 150 \\
\hline KEMASYARAKATAN &, 397 &, 132 &, 454 \\
\hline LINGKUNGAN &, 558 &, 130 & \\
\hline MOTIVASI & & & & \\
\hline
\end{tabular}

Sumber : Data Olahan (2020)

Berdasarkan tabel di atas, maka persamaan regresi linear berganda ialah sebagai berikut :

$$
\begin{array}{r}
\gamma=a+b_{1} X_{1}+b_{2} X_{2}+b_{3} X_{3}+b_{4} X_{4} \\
\gamma=5,140+0,533 X_{1}+0,397 X_{2} \\
+0,397 X_{3}+0,558 X_{4}
\end{array}
$$

Berdasarkan angka-angka dalam persamaan regresi linear berganda di atas, maka dapat dijelaskan sebagai berikut :

1. Nilai Konstan (a) adalah sebesar 5,140. Artinya apabila Pribadi, Kemasyarakatan, Lingkungan dan Motivasi diasumsikan nol (0), maka Minat Berwirausaha (Y) bernilai 5,140.

2. Nilai koefisien regresi variabel Pribadi $\left(\mathrm{X}_{1}\right)$ adalah sebesar 0,533. Artinya bahwa setiap peningkatan Faktor Pribadi sebesar 1 satuan maka akan meningkatkan Minat Berwirausaha (Y) sebesar 0,533 dengan asumsi variabel $\mathrm{X}_{2}, \mathrm{X}_{3}$, dan $\mathrm{X}_{4}$ tetap.

3. Nilai koefisien regresi variabel Kemasyarakatan $\left(\mathrm{X}_{2}\right)$ adalah sebesar 0,397. Artinya adalah bahwa setiap peningkatan Faktor Kemasyarakatan sebesar 1 satuan maka akan meningkatkan Minat Berwirausaha (Y) sebesar 0,397 dengan asumsi variabel $\mathrm{X}_{1}, \mathrm{X}_{3}$, dan $\mathrm{X}_{4}$ tetap.

4. Nilai koefisien regresi variabel Lingkungan $\left(\mathrm{X}_{3}\right)$ adalah sebesar 0,397. Artinya bahwa setiap peningkatan Faktor Lingkungan sebesar 1 satuan maka akan meningkatkan Minat Berwirausaha (Y) sebesar 0,397 dengan asumsi variabel $\mathrm{X}_{1}, \mathrm{X}_{2}$, dan $\mathrm{X}_{4}$ tetap.

5. Nilai koefisien regresi variabel Motivasi $\left(\mathrm{X}_{4}\right)$ adalah sebesar 0,558. Artinya bahwa setiap peningkatan Faktor Motivasi sebesar 1 satuan maka akan meningkatkan Minat Berwirausaha (Y) sebesar 0,558 dengan asumsi variabel $\mathrm{X}_{1}, \mathrm{X}_{2}$, dan $\mathrm{X}_{3}$ tetap.

\section{Uji Parsial (Uji-t)}

Uji-t dilakukan untuk mengetahui pengaruh masing-masing variabel bebas terhadap variabel terikat dengan menggunakan SPSS For Windows Versi 24.0, dapat dilihat pada tabel berikut ini : 
Tabel 6. Perhitungan Uji-t

\begin{tabular}{|c|c|c|c|c|c|c|}
\hline \multicolumn{7}{|c|}{ Coefficients $^{a}$} \\
\hline & & \multicolumn{2}{|c|}{$\begin{array}{l}\text { Unstandardized } \\
\text { Coefficients }\end{array}$} & \multirow{2}{*}{$\begin{array}{c}\begin{array}{c}\text { Standardized } \\
\text { Coefficients }\end{array} \\
\text { Beta }\end{array}$} & \multirow[b]{2}{*}{$\mathrm{T}$} & \multirow[b]{2}{*}{ Sig. } \\
\hline \multicolumn{2}{|c|}{ Model } & $\mathrm{B}$ & Std. Error & & & \\
\hline 1 & (Constant) & 5,140 & 2,540 & & 2,024 & ,047 \\
\hline & PRIBADI & .533 & 138 & 362 & 3,879 & 000 \\
\hline & KEMASYARAKATAN & 397 &, 124 & 255 & 2,393 &, 004 \\
\hline & LINGKUNGAN & 397 &, 132 & 150 & 1,819 &, 016 \\
\hline & MOTIVASI & 558 &, 130 &, 454 & 4,306 &, 000 \\
\hline
\end{tabular}

Sumber : Data Olahan (2020)

Dari hasil pengolahan di atas dapat diketahui bahwa :

1. Nilai $t_{\text {hitung }}$ variabel Pribadi $\left(X_{1}\right)$ sebesar 3,879 dan nilai $t_{\text {tabel }} 1,671$ dengan tingkat signifikan sebesar 0,05 dan derajat kebebasan sebesar 71 $(\mathrm{dk}=\mathrm{n}-\mathrm{k}-1(76-4-1=71))$ maka akan terlihat bahwa : $t_{\text {hitung }}>$ $t_{\text {tabel }}$ atau 3,879>1,671. Hal ini menunjukkan bahwa $\mathrm{H}_{0}$ ditolak dan $\mathrm{H}_{1}$ diterima, sehingga dapat dikatakan bahwa terdapat pengaruh yang signifikan antara Pribadi terhadap Minat Berwirausaha.

2. Nilai $t_{\text {hitung }}$ variabel Kemasyarakatan $\left(\mathrm{X}_{2}\right)$ sebesar 2,393 dan nilai $t_{\text {tabel }} 1,671$ dengan tingkat signifikan sebesar 0,05 dan derajat kebebasan sebesar 71 $(\mathrm{dk}=\mathrm{n}-\mathrm{k}-1(76-4-1=71))$ maka akan terlihat bahwa : $t_{\text {hitung }}>$ $t_{\text {tabel }}$ atau 2,393>1,671. Hal ini menunjukkan bahwa $\mathrm{H}_{0}$ ditolak dan $\mathrm{H}_{2}$ diterima, sehingga dapat dikatakan bahwa terdapat pengaruh yang signifikan antara Kemasyarakatan terhadap Minat Berwirausaha.

3. Nilai $t_{\text {hitung }}$ variabel Lingkungan $\left(X_{3}\right)$ sebesar 1,819 dan nilai $t_{\text {tabel }} 1,671$ dengan tingkat signifikan sebesar 0,05 dan derajat kebebasan sebesar 71 $(\mathrm{dk}=\mathrm{n}-\mathrm{k}-1(76-4-1=71))$ maka akan terlihat bahwa : $t_{\text {hitung }}>$ $t_{\text {tabel }}$ atau $1.819>1,671$. Hal ini menunjukkan bahwa $\mathrm{H}_{0}$ ditolak dan $\mathrm{H}_{3}$ diterima, sehingga dapat dikatakan bahwa terdapat pengaruh yang signifikan antara Lingkungan terhadap Minat Berwirausaha.

Nilai $t_{\text {hitung }}$ variabel Motivasi $\left(\mathrm{X}_{4}\right)$ sebesar 4,306 dan nilai $t_{\text {tabel }}$ 1,671 dengan tingkat signifikan sebesar 0,05 dan derajat kebebasan sebesar $71 \quad(\mathrm{dk}=\mathrm{n}-\mathrm{k}-$ $1(76-4-1=71))$ maka akan terlihat bahwa : $t_{\text {hitung }}>t_{\text {tabel }}$ atau 4,306 $>1,671$. Hal ini menunjukkan bahwa $\mathrm{H}_{0}$ ditolak dan $\mathrm{H}_{4}$ diterima, sehingga dapat dikatakan bahwa terdapat pengaruh yang signifikan antara Motivasi terhadap Minat Berwirausaha.

Maka secara parsial dapat diketahui bahwa variabel bebas yang paling dominan mempengaruhi Minat Berwirausaha Mahasiswa Prodi Ekonomi Syariah Universitas Islam Riau adalah Faktor Motivasi $\left(\mathrm{X}_{4}\right)$ sebesar 4,306.

\section{Uji Simultan (Uji-F)}

Uji-F digunakan untuk mengetahui pengaruh masing-masing variabel bebas terhadap variabel terikat. Hasil pengujian Uji-F menunjukkan bahwa $F_{\text {hitung }}$ sebesar 30,214, sedangkan $F_{\text {tabel }}$ pada taraf signifikan $(\alpha) 5 \%$ dengan df 1 sebesar 3 $(k-1=4-1)$, df 2 sebesar $71(n-k-$ $1=76-4-1)$, maka $F_{\text {tabel }}$ diperoleh sebesar 2,74 .

Maka $F_{\text {hitung }}>F_{\text {tabel }}$ yaitu 30,214 $>$ 2,74 yang berarti bahwa $\mathrm{H}_{0}$ ditolak. Artinya bahwa variabel independen (Pribadi, Kemasyarakatan, Lingkungan, Motivasi) secara bersama-sama berpengaruh signifikan 
terhadap variabel dependen (Minat Berwirausaha).

\section{Koefisien Korelasi}

Untuk mengetahui hubungan antara variabel bebas terhadap variabel terikat, maka digunakan koefisien korelasi dengan menggunakan SPSS For Windows Versi 24.0.

Tabel 7. Analisis Korelasi

\begin{tabular}{ll|rrrr}
\hline \multicolumn{5}{c}{ Model Summary $^{\mathrm{b}}$} \\
\hline Model & $\mathrm{R}$ & \multicolumn{2}{c}{ R Square } & \multicolumn{1}{c}{ Adjusted R Square } & \multicolumn{2}{c}{ Std. Error of the Estimate } \\
\hline 1 &, $794^{\mathrm{a}}$ &, 630 &, 609 & 1,572 \\
\hline
\end{tabular}

Sumber: Data Olahan (2020)

Dari hasil pengolahan SPSS Nilai $R$ menunjukkan korelasi ganda antara variabel independen dengan variabel dependen. Dari tabel di atas diketahui nilai $\mathrm{R}$ sebesar 0,794 $(79,4 \%)$. Artinya korelasi ganda antara variabel $\mathrm{X}$ (Pribadi, Kemasyarakatan, Lingkungan, Motivasi) dengan variabel $\mathrm{Y}$ (Minat Berwirausaha) memiliki hubungan yang kuat.

\section{Koefisien Determinasi}

Diketahui nilai Adjusted $R$ Square sebesar 0,609. Artinya bahwa sumbangan pengaruh variabel independen $(\mathrm{X})$ (Pribadi, Kemasyarakatan, Lingkungan, Motivasi) dengan variabel dependen (Y) (Minat Berwirausaha) adalah sebesar 60,9\%, sedangkan sisanya sebesar $39,1 \%$ dipengaruhi oleh variabel lain yang tidak dimasukkan dalam penelitian ini. Berdasarkan hasil penelitian di atas diketahui bahwa Faktor-Faktor yang Mempengauhi Minat Berwirausaha Mahasiswa Prodi Ekonomi Syariah Universitas Islam Riau adalah Faktor Pribadi, Faktor Kemasyarakatan, Faktor Lingkungan dan Faktor Motivasi. Pembahasan hasil temuan menunjukkan bahwa faktor pribadi, kemasyarakatan, lingkungan dan Motivasi berpengaruh terhadap minat berwirausaha. maka dapat disimpulkan bahwa hipotesis diterima.

Secara parsial dapat diketahui bahwa variabel bebas yang paling dominan mempengaruhi Minat Berwirausaha Mahasiswa Prodi Ekonomi Syariah Universitas Islam Riau adalah Faktor
Motivasi $\left(\mathrm{X}_{4}\right)$ sebesar 4,306. Secara simultan dapat diketahui $F_{\text {hitung }}>F_{\text {tabel }}$ yaitu 30,214 $>2,74$ yang berarti bahwa $\mathrm{H}_{0}$ ditolak. Artinya adalah bahwa variabel independen (Pribadi, Kemasyarakatan, Lingkungan, Motivasi) secara bersama-sama berpengaruh signifikan terhadap variabel dependen (Minat Berwirausaha).

Hubungan antara variabel X (faktor pribadi, kemasyarakatan, lingkungan dan motivasi) dengan variabel $\mathrm{Y}$ (minat berwirausaha) termasuk dalam kategori hubungan yang kuat. Hal ini diketahui dari nilai koefisien korelasi (R) sebesar 79,4\%. Pengaruh variabel independen (pribadi, kemasyarakatan, lingkungan, motivasi) terhadap variabel dependen (Minat Berwirausaha) yang dapat diketahui dari koefisien determinasi sebesar 60,9\%, sedangkan sisanya sebesar $39,1 \%$ dipengaruhi oleh variabel lain yang tidak dimasukkan dalam penelitian ini.

\section{KESIMPULAN}

Berdasarkan pembahasan di atas maka dapat disimpulkan bahwa Berdasarkan uji parsial, faktor yang paling dominan yaitu Faktor Motivasi Terhadap Minat Berwirausaha Mahasiswa Prodi Ekonomi Syariah Universitas Islam Riau dan yang menyatakan signifikan adalah Faktor Pribadi, Faktor Kemasyarakatan, Faktor Lingkungan. Berdasarkan uji simultan, dapat disimpulkan terdapat pengaruh yang signifikan antara Faktor Pribadi, Faktor Kemasyarakatan, Faktor Lingkungan dan Faktor Motivasi terhadap Minat Berwirausaha Mahasiswa 
Prodi Ekonomi Syariah Universitas Islam Riau. Berdasarkan analisis korelasi antara variabel bebas (Faktor Pribadi, Faktor Kemasyarakatan, Faktor Lingkungan, Faktor Motivasi) dengan variabel terikat (Minat Berwirausaha) memiliki hubungan yang kuat. Pengaruh variabel bebas (Faktor Pribadi, Faktor Kemasyarakatan, Faktor Lingkungan, Faktor Motivasi) terhadap variabel terikat (Minat Berwirausaha) berpengaruh kuat yaitu sebesar 60,9\%, sedangkan sisanya sebesar $39,1 \%$ dipengaruhi oleh variabel lain yang tidak dimasukkan dalam penelitian ini.

\section{DAFTAR PUSTAKA}

Adhitama, Paulus Patria. 2014. FaktorFaktor yang Mempengaruhi Minat Berwirausaha (Studi Kasus Mahasiswa Ekonomika dan Bisnis, UNDIP Semarang). Skripsi Fakultas Ekonomika dan Bisnis UNDIP. Semarang.

Alma, Buchari. 2017. Kewirausahaan : Untuk Mahasiswa dan Umum. Alfabeta. Bandung.

Astuti, Daharmi., \& Maharani, Deswita. 2015. Kompetensi Lulusan Sarjana Ekonomi Syariah dalam Dunia Kerja (Urgensi dan Harapan). Jurnal AlHikmah, 12(2), p. 132-151.

Ayuningtias, Hazirah Amalia., \& Ekawati, Sanny. 2015. Faktor-Faktor yang Mempengaruhi Minat Berwirausaha pada Mahasiswa Fakultas Ekonomi Universitas Tarumanagara. Jurnal Ekonomi, 20(1), p. 49-71.

Daryanto \& Cahyono, Aris Dwi. 2013. Kewirausahaan : Penanaman Jiwa Kewirausahaan. Gava Media. Yogyakarta.

Djali. 2013. Psikologi Pendidikan. Bumi Aksara. Jakarta.

Farid. 2017. Kewirausahaan Syariah. Kencana. Depok.

Fauzan, Ahmad. 2012. Analisis FaktorFaktor yang Mempengaruhi Minat
Membuka Usaha Butik Busana Muslim di Kota Pekanbaru. Skripsi. Fakultas Agama Islam Jurusan Ekonomi Syariah Universitas Islam Riau. Pekanbaru.

Kambuaya, Carlos. 2015. Pengaruh Motivasi, Minat, Kedisiplinan dan Adaptasi Diri Terhadap Prestasi Belajar Siswa Peserta Program Afirmasi Pendidikan Menengah Asal Papua dan Papua Barat di Kota Bandung. Social Work Jurnal, 5(2), p. $157-166$.

Mahanani, Estu., \& Sari, Bida. 2018. FaktorFaktor yang Mempengaruhi Minat Berwirausaha Mahasiswa Fakultas Ekonomi Universitas Persada Indonesia. Ikraith-Humaniora, 2(2), p. $31-40$.

Misbahuddin \& Hasan, Iqbal. 2014. Analisis Data Penelitian dengan Statistik. Bumi Aksara. Jakarta.

Norvadewi. 2015. Bisnis dalam Perspektif Islam (Telaah, Konsep dan Landasan Normatif). Al-Tijary: Jurnal Ekonomi dan Bisnis Islam, 1(1), p. 35-37.

Primandaru, Noormalita. 2017. Analisis Faktor-Faktor yang Berpengaruh pada Minat Berwirausaha Mahasiswa. Jurnal Economia, 13(1), p. 68-78.

Riduwan. 2018. Dasar-Dasar Statistik. Alfabeta. Bandung.

Sanusi, Anwar. 2016. Metodologi Penelitian Bisnis. Salemba Empat. Jakarta.

Syah, Muhibbin. 2011. Psikologi Belajar. RajaWali Pers. Jakarta. 